\title{
On Construction of Service-oriented Organs in Universities from the Perspective of Reform on Official Seal System
}

\author{
Kai Zhang \\ Party Committee office and President Office, \\ North China Electric Power University \\ Beijing, China \\ 30661172@qq.com
}

\author{
Yuxi Yuan \\ International Education Institute, \\ North China Electric Power University \\ Beijing, China \\ amiyuxi@126.com
}

\begin{abstract}
As the gateway to the outside and the model for other sectors inside, the university administrative organ is both an administration of various issues and a provider of many services. As a result, the quality of its services directly exerts influence on the external image as well as work and study of teachers and students within the university. Taking the reform on official seal system of North China Electric Power University as an example, the authors analyze the change in management service ideas and means, find deficiencies in current construction of service-oriented organs in universities, and thus put forward three suggestions for construction of service-oriented organs in universities, namely, enhance service awareness by providing better service in daily examination and approval, simplify the approval process and reform the service system, and innovate in propaganda carriers and adopt flexible service forms. In conclusion, the construction of service-oriented organs is an eternal and endless work which is frequently done.
\end{abstract}

Keywords-university; reform; official seal system; serviceoriented organ

\section{CASE \& INTRODUCTION}

"I applied to seal various documents by the University Office, and often forgot the procedures required if I did not apply to seal for some time. Besides, the sectors of examination and approval varied even if you applied to use the very same seal but for different issues, so did the procedures required. Sometimes I was too shy to ask the staff since I had too many questions for each procedure. Now I am so happy to learn that not only the procedures are simplified, but frequent problems and models are clearly listed, so that I never have to worry that I cannot seal documents even I go there for many times." Such is what staff hear after the reform on official seal system by Party Committee office and President Office (hereinafter referred to as "University office") of North China Electric Power University.

Every year, the University Office receives thousands of application for seal, about half of which are put forward by teachers and students that apply for the first time. For lack of knowledge on procedures and various ways of interpreting those policies, many people do not manage to seal although they have been to several departments of examination and approval. On the one hand, these applicants, who assume that they have sound reasons, usually see necessary procedures of examination as "torture"; some people are in such a hurry that they may even ask to seal without examination. On the other hand, faced with ever-increasing needs for seal, complex approval procedures and disparate standards of sealing, staff of the University Office have to ask for instruction from his leaders about what to do. As a result, no matter how kind and patient the staff are, applicants get angry and discontent after they are told what they should do or should not do.

In order to better "study Party Constitution of Chinese Communist Party, study and implement important spirits of a series of speeches by $\mathrm{Xi}$ Jinping, General Secretary of Communist Party of China, and be qualified party members", the University Office starts to standardize application procedures, optimize "Seal Approval Form" and make a template, with enlightenment of measures by the Government Affairs Hall, research into other universities and suggestions of teachers and students. Guided by the principles of standardization, high efficiency and practicability, office staffs combine "Application Form for Copies of Organization Code Certificate and Certificate of Legal Person" and "Seal Approval Form" into one form, delete the box of "seal type", substitute the blank of "type of seal" which needs to be filled in with a list to be ticked, and add a box of "agent". With experience of routine work, office staffs draw a new flowchart and make a template with sufficient tips, which are drawn on acrylic plates and put on desks in the office, sent to departments with much need for seal, and issued on office websites to be easily downloaded by any teacher and student. Through this service, University Office tries to inform people of the approval process and help them apply to seal successfully at a time, which avoids "disorder, slowing, and mistake" as well as serve teachers and students considerately.

\section{ENLIGHTENMENT OF REFORMING OFFICIAL SEAL}

\section{SySTEM ON CONSTRUCTION OF SERVICE-ORIENTED ORGANS}

With standardized administration and better service for teachers and students as the ultimate goal, the University Office reforms on official seal system, promotes service management instead of simply answering questions when necessary, and embodies "standard, high-efficient and downto-the-earth" work ethics. 


\section{A. Promote active service in thought}

The change in thought serves as impetus of reform. In this reform on official seal system, the staff of the University Office change their attitude from "we are forced to do ..." to "we want to do ..." They will not refuse callously or find excuses if applicants do not prepare well for getting the seals. Instead, they actively try to find and solve these problems with proper means. In addition, they improve their working styles by transforming concentration on leaders and staff themselves to teachers and students. As a result, they are able to offer "one-stop service" with sufficient guidance and convenience.

\section{B. Boost people-oriented service in system design}

Nothing can be accomplished without norms and standards. As administrators of university daily affairs, organ staff must rely on rules and regulations as both basis and means. As the idea of "people orientation" requires, university organs should never make rules and regulations only from their own point of view. Instead, organs should stay close to the applicants, fully understand their needs, and carefully consider operability. For instance, some teachers, especially those shouldering both professional and administrative responsibilities, are too busy to spare much time for such application. As a result, the University Office now entitles agents to apply for seals as long as they hold sufficient documents. In addition, humanization and flexibility are embodied in design of the application form. Many blanks to be fulfilled previously are substituted by options to be ticked, and items of the same nature or issues to be approved by the same person are combined reasonably to simplify procedures.

\section{Advocate that "service is the most significant"in practical work}

Service and management coexist. Service-oriented organs are characterized mainly by service assisted by rigid management. After the reform on official seal system, efforts are made in clearing up and simplifying various affairs, and many procedures are simplified or merged. The new flowchart is drawn and template on frequent issues are edited. The soft copy of flowchart and template is publicized both in the University Office and in other sectors that frequently apply to seal, so that faculty and students quickly learn new rules. Such measures standardize application, improve work efficiency, and ultimately enhance satisfaction of teachers and students, illustrating "service is the most significant".

\section{Current InAdeQuacy In Services Provided By UNIVERSITY ORGANS}

In recent years, university service-oriented organs make remarkable achievements with guidance and requirement of "improving working style and offering satisfactory education" by the Central Committee of the Communist Party of China and Ministry of Education of the People's Republic of China. However, there are still problems such as weak service awareness, antiquated forms, insufficient publicity and nonfeasance in practical work. It seems that the comment that "you cannot have easy access to the office, the staff may hold bad attitude with harsh works, and it is really difficult to handle business affairs" is the very microcosm of various organs. University organs are not exception. With many large organs with more personnel than needed, many university organs run with low efficiency and function with less serviceoriented management [1]. Specifically speaking, some staff only have a smattering of superficial knowledge to some extent, never attend on-the-job training, and therefore cannot do the job well because of lack of vocational studies; some staff only work under command of superiors, but never consider what teachers and students need; some staff swiftly complete tasks allocated by higher authorities, but drag their heels when faced with appeals of ordinary people; some prevaricate and dispute over trifles in work; some observe all rules and regulations with narrow train of thought and conventional ways; and lack of communication is usually seen among sectors and departments.

\section{Suggestions on COnStruction of SERVice- ORIENTED ORGANS IN UNIVERSITIES}

The key to construction of service-oriented organs in universities is to understand basic characteristics. Such organs should offer quality service to teaching and scientific study with universities, teachers and students as the center, innovation as the premise, competency as the basis, and efficiency as the focus [2]. Service-oriented organs are featured by the idea of serving the public, principle of abiding by laws as well as practicality so as to ultimately satisfy public needs.

\section{A. Enhance service awareness by providing better service in daily examination and approval}

Enhance service awareness by providing better service in daily examination and approval rather than enhancing management. As Confucianism proposes, we can only give full scope to the talents, make the best use of everything, and achieve harmony and peace with correct thought, conception and attitude toward work. We should reside management in service by enhancing the concept of public servants and the idea of "offering infinite service in finite examination and approval". Specific recommendations are listed as follows.

1) Organize seminars and workshops regularly to enhance service awareness through study and summary, which is the first step to construct service-oriented organs.

2) Make use of various activities, such as position exchanges, daily work reproductions and knowledge contests, to find problems through more vivid forms and deepen understanding of the important service-oriented construction.

3) Cadres of university organs should enhance service concept and change service patterns, emancipate their minds, strengthen the overall situation awareness, attach importance to team work, and promote communication between various departments.

4) Senior administrative staff should make full use of humanistic care in construction of service-oriented organs. Humanistic care should never be superficial and formal requirements. 
5) Organs should change the past serious patterns and styles, put down airs of greatness, build up service-oriented window, stick strictly to the idea of "offering infinite service through finite examination and approval", wholeheartedly serve the masses, the basic level, and development.

\section{B. Simplify the approval process and change the service system from mechanization to humanization}

Simplify the approval process and adopt flexible forms. The university office tries to shorten time and improve efficiency by centralized examination and approval, simplified procedures with better attitude.

1) Examine and approve all relevant applications in the university office or other authorized offices.

2) Strictly implement service commitment, one-time notification and short process services [3]. Service commitment means to finish all proceedings within promised time to ensure efficiency [4].

3) Provide new and convenient ways, such as booking services and online approval, to save time for both staff and applicants.

4) Publicize approval guide and procedures to facilitate application, simplify procedures, save time and improve efficiency.

5) Allocate numbers to those who do not appoint in advance to keep sound order. Staff can check whether the application should be submitted to this office before applicants get their numbers. When queuing, applicants can fill in necessary forms according to required procedures. In this way, university office increases degree of satisfaction from teachers and students as well as saves the time of staff, providing better service ultimately.

\section{Innovate propaganda carriers, and transform service from traditional styles to informationalized styles [5]}

University office should standardize work procedures, put forward quantitative criteria for rules and regulations, and allocate tasks and requirements to the very post and specific staff via information means, and build a strict system of process control system, so as to link all procedures in management. Staff should try to fulfill the following tasks.

1) Offer sufficient channels of communication, such as fixed-line telephones, mobile phones, emails, micro-blogs, QQ and WeChat, to ensure "users" to acquire necessary information and notification anywhere at any time, so as to create a sound barrier-free precondition anywhere at any time for service-oriented management.

2) Construct a shared information database and a public platform for administrative management information to promote dissemination of administrative information in universities, prompt staff to prepare to carry responsibilities, lay emphasis on both effects and feedbacks, so that teachers and students can have access to dynamic administrative information in time, and supervise and evaluate management of university organs.
3) Pursue the "Goldfish-Bowl Effect" by supervising and commenting on management of university organs through the public platform of information and services. In other words, university organs and staff should be examined and judged by all teachers and students within the university, just like goldfishes in the fish tank [6], so as to promote transparency and openness in the process of performance evaluation.

4) Establish and improve organ intranet to realize online disposition of administrative affairs as much as possible, and boost dissemination of administrative information.

\section{Conclusion}

In conclusion, both service and management are core functions of university organs, which office services and ensure normal running of the whole university. In practical work, on the one hand, procedures and systems are important means of management, which embody regulation and restraint by organs, while on the other hand, service is the ultimate purpose, the quality of which decides the work level of organs. As Xi Jinping, general secretary of the Communist Party of China, says, "we should reside management in service, which means carry out management in service and embody service in management," which should be learned by heart by university organ staff in construction of service-oriented organs. We should have the courage to break through fixed procedures and thinking set with regard to new circumstances, situations and development in "New Normal". We should frequently check whether current rules, regulations and procedures meet requirement of the new era, and whether any improvement is needed. We should always ask ourselves whether service can be further improved based on existing experiences and practices? [7] By all the above means, we are sure to correctly handle the relationship between service and principle, and provide quality service to the very last step.

\section{REFERENCES}

[1] Fang Wang, "On Reinforcement of Administrative Construction of Service in Institution of Higher Learning," Journal of Dalian Education University, Vol. 22, pp. 35-36, Mar 2006. (In Chinese)

[2] Xiaomi Zhang, Hong Zhang, Junlin Wang, "Theoretical and Practical Exploration on Construcation of Service-oriented Organs in Universities," Heilongjiang Education (Theory \& Practice), Vol. 5, pp. 49-50, May 2014. (In Chinese)

[3] Hongkai Nie, Zhiwei Liu, Rongmao Li, "Transformation from 'Management' to 'Service-oriented' - The Exploration and Practice of the Construction of CPC at the Service-type Authority at Jilin University," New March, Vol. 1, pp. 26-27, Jan 2016. (In Chinese)

[4] Liming Wang, "Research on the Way of Reinforcement Service Style Construction of Administration in Colleges and Universities," Journal of Wuyi University, Vol.30, pp.81-85, Feb 2011. (In Chinese)

[5] Danni Zhang, "Preliminary Discussion on Innovation, Experiences and Practice of Service-oriented Organs in Universities," Asia-Pacific Education, Vol. 24, pp. 201, Aug 2016. (In Chinese)

[6] Yitao Huang, Jingjing Li. "Construction of Service-oriented Organs in Universities with Scientific Outlook on Development as the Guidance," Truth Seeking, Vol.1, pp. 278-280, Jun 2010. (In Chinese)

[7] Rui Zhu, "Four Self-examinations on Improving Management and Service," Office Operations, Vol. 2, pp. 17, Feb 2013. (In Chinese) 